\title{
Expression of Ki-67, Bcl-2 and Bax in the First Trimester Abortion Materials
}

\section{Illk Trimester Abortus Materyallerinde Ki-67, Bcl-2 ve Bax Ekspresyonu}

\author{
Canan KELTEN' ${ }^{\text {, Osman ZEKIOĞLU }}{ }^{2}$, Coşan TEREK ${ }^{3}$, Necmettin ÖZDEMIR ${ }^{2}$, Ender DÜZCAN ${ }^{1}$ \\ Department of Pathology, ${ }^{1}$ Pamukkale University, Faculty of Medicine, DENIZLI, ${ }^{2}$ Ege University, Faculty of Medicine, IZMIR and \\ ${ }^{3}$ Department of Gynecology and Obstetrics, Ege University, Faculty of Medicine, IZMIR, TURKEY
}

This study has been supported by PAUBAP (2005 TPF 006)

\section{ABSTRACT}

Objective: The aim of this study was to investigate possible similar or different mechanisms in recurrent and spontaneous abortion by evaluating immunohistochemical correlation between proliferation marker Ki-67, and apoptosis markers Bcl-2 and Bax in the fetal trophoblasts and maternal deciduas from abortion material.

Material and Method: Eighty samples of curettage materials from 65 abortion patients histopathologically diagnosed "decidua showing Arias-Stella reaction and chorionic villi" or only "decidua showing Arias-Stella reaction" were included in the study. Hematoxylin\&Eosin stained sections from all cases were re-evaluated and further stained immunohistochemically using antibodies against Ki-67, Bcl-2 and Bax.

Results: Proliferation rate evaluated by Ki-67 expression both in the cytotrophoblastic cells and decidua was found to be significantly lower in spontaneous and recurrent abortions compared to evacuation abortion. The extent of Bcl-2 expression in syncytiotrophoblastic cells covering villous stroma was also decreased in spontaneous abortion. There were no significant differences between spontaneous and recurrent abortions in terms of Bcl-2 expression in syncytiotrophoblasts and Ki-67 proliferation index in cytotrophoblastic cells or decidua. Bax staining showed minimal decidual expression in a few spontaneous and recurrent abortions.

Conclusion: We concluded that proliferation rate was decreased in fetal villous cytotrophoblasts and maternal deciduas in spontaneous and recurrent abortions. We also proposed that loss of Bcl-2 expression in syncytiotrophoblasts may cause abortion in a subset of cases. However, the data from spontaneous and recurrent abortions did not not support the presence of different mechanisms in both groups.

Key Words: Abortion, Cell proliferation, Apoptosis, Ki-67, Bcl-2, Bax
ÖZ

Amaç: Bu çalışmada, düşük materyallerinde, fötal trofoblastlar ve maternal desiduada, immünhistokimyasal olarak proliferasyon belirleyicisi (Ki-67) ve apoptoz ile ilgili belirleyiciler (Bcl-2 ve Bax) arasındaki ilişkiyi değerlendirerek, spontan ve reküran abortus olgularında benzer ya da farklı mekanizmaların varlığını araştırmayı amaçladık.

Gereç ve Yöntem: Histopatolojik olarak değerlendirilen küretaj materyallerinde "Arias-Stella reaksiyonu gösteren desidua ve koryon villusları" veya "gebelik ürünü” tanısı almış 65 hastaya ait 80 doku örneği çalışmaya alındı. Olgulara ait Hematoksilen\&Eozin boyalı kesitler tekrar değerlendirildi ve seçilen kesitler immünohistokimyasal olarak Ki-67, Bcl-2 ve Bax ile boyand.

Bulgular: Abortus olgularında, hem desiduada hem de koryon villuslarını döşeyen sitotrofoblastik hücrelerde Ki-67 ile değerlendirilen proliferasyon miktarı tahliye küretaj olgularından anlamlı olarak daha düşük saptandı. Abortus olgularında koryon villuslarını döşeyen sinsityotrofoblastlarda eksprese edilen $\mathrm{Bcl}-2$ yaygınlığı, tahliye küretaj olgularına göre azalmış izlendi. Spontan ve rekürren abortus olguları arasında, desidua ve koryon villuslarında Ki-67 proliferasyon indeksi ya da villusları döşeyen sinsityotrofoblastlarda eksprese edilen Bcl-2 yaygınlığı arasında anlamlı farklılık saptanmadı. Bax ile az sayıda abortus olgusunda desiduada düşük düzeyde ekspresyon izlendi.

Sonuç: Abortus olgularında fötal villöz sitotrofoblastlar ve maternal desidual dokularda proliferasyon oranının azaldığı sonucuna vardık. Sinsityotrofoblastlarda Bcl-2 ekspresyon kaybının bir grup olguda abortusa yol açabileceğini düşündük. Bununla birlikte, spontan ve reküran abortus olgularında elde edilen bulgular, bu iki grupta farkl mekanizmaların geçerli olabileceği görüşünü destekler nitelikte değildi.

Anahtar Sözcükler: Abortus, Hücre proliferasyonu, Apoptoz, Ki-67, Bcl-2, Bax 


\section{INTRODUCTION}

Spontaneous abortion is the spontaneous end of a pregnancy and is usually seen before the 12th week of pregnancy. $45-50 \%$ of clinically confirmed and $15 \%$ of unconfirmed pregnancies results in spontaneous abortion (1). The most common cause of spontaneous abortions is chromosomal abnormalities at present and abnormal karyotypes in order of frequency are autosomal trisomy, 45XO monosomy, triploidy and tetraploidy $(2,3)$. Other causes of spontaneous abortion include immunological abnormalities, endocrinemetabolic disorders and congenital uterine abnormalities.

The exact mechanism of spontaneous abortion has not been understood yet (4). Recently, studies attempting to evaluate apoptosis in normal and abnormal pregnancies have drawn attention. This has led to intensive investigation of proliferation markers such as Ki-67 and proliferating cell nuclear antigen (PCNA) as well as many apoptosis-related genes or proteins mainly p53 and Bcl-2 and others (e.g. Fas/FasL system, Bax, bad, bid, Bcl-x, bak, p21, c-myc, cerb-B2, RB, CD56, a group of caspase family, EGF, EGF-R, TGF- $\beta$, MMP-2) in feto-maternal tissues.

Apoptosis is a type of programmed cell death controlled at the gene level. It plays an important role in embryonic development, maintenance of tissue homeostasis and elimination of cells with severe DNA damage (5). Disturbances in regulation of cellular proliferation and apoptosis can directly or indirectly lead to fetal growth retardation and loss of pregnancy. For example, experimental stimulation of apoptosis by nitric oxide synthase inhibitors has caused marked decrease in fetal and placental size. The rate of apoptosis in 3rd trimester placentas with growth retardation has been reported to be much higher than normal 3rd trimester placentas (1). Experimental studies in rats have shown apoptotic cell death in the uterine epithelial cells surrounding embryos during implantation and in gonadal tissues $(4,6,7)$. Antimesometrial decidual cell death due to apoptosis in rats has also been reported (4). Apoptotic cell death has also been defined in humans in the mid- or late luteal phase corpus luteum, and the late secretory, menstrual or early proliferative endometrium $(4,6-8)$. Definition of apoptotic changes during the early pregnancy may therefore contribute to the prevention of unwanted abortions and recurrent loss of pregnancy.

The aim of this study was to analyze the agents that play a role in the apoptotic process by evaluating the relations between a proliferation marker (Ki-67) and apoptosisrelated markers (Bcl-2, and $\mathrm{Bax}$ ) immunohistochemically in abortion materials, fetal trophoblasts, and maternal deciduas, and to investigate the presence of similar or different mechanisms in recurrent and spontaneous abortions.

\section{MATERIAL and METHOD}

Curettage material of 67 specimens from 55 patients histopathologically diagnosed "decidua showing AriasStella reaction and chorionic villi" or only "decidua showing Arias-Stella reaction" at Pamukkale University, Faculty of Medicine, Department of Pathology between May 1996 and June 2004 and 14 specimens from 11 patients diagnosed "products of conception" at Ege University, Faculty of Medicine, Department of Pathology between 2001 and 2003 were determined. Archival hematoxylin-eosin (H\&E) stained sections from $10 \%$ buffered formaldehyde fixed and paraffin embedded tissues of the specimens were re-evaluated. One tissue sample was excluded from the study because of tissue disintegration during repeated immunohistochemical procedures. A total of 80 specimens from 65 patients were included in the study.

Information on the patient's last menstrual period, the period in which the abortion took place in the 1st trimester, demonstration of unembryonic pregnancy or fetal death by USG, the patient's age and whether she had taken any medication during the pregnancy and the presence of any other infectious, autoimmune and/or other systemic/local disease was obtained from the pathology reports, and patient files and by telephone interview methodology.

The spontaneous abortion specimens included in this study consisted of abortus imminens, abortus incipiens, abortus incompletus and abortus completus in the first trimester of pregnancy (first 12 weeks) that had ended with loss of pregnancy once or twice. Recurrent abortion specimens included cases with no previous history of healthy birth, and cases with at least three consecutive losses of pregnancy in the first trimester. Abortus imminens defined abortions with mild bleeding while abortus incipiens defined abortions with cervical opening and dilatation within the first 12 weeks. Complete abortion was complete expulsion of the dead fetus from the uterine cavity while this process was incomplete in incomplete abortion.

The H\&E-stained sections from all specimens were reevaluated and tissue samples that contained decidua and chorionic villi sustaining tissue integration without areas of hemorrhage and necrosis as much as possible were obtained. 4-5 $\mu \mathrm{m}$ thick sections from selected paraffin blocks were put on Poly-L-lysine slides, and deparaffinized at $60^{\circ} \mathrm{C}$ in the incubator for one night. The sections were kept in xylene 
twice for 30 minutes, rehydrated in absolute alcohol, 95\% ethanol, $80 \%$ alcohol, and $70 \%$ ethanol (three times) each for 2 minutes, and then washed in distilled water. Antigen retrieval was performed for Ki-67 (10 min., citrate buffer pH:6, 700 Watt microwave oven) and Bcl-2 and Bax (high temperature: $10 \mathrm{~min}$., moderate and low temperature: 5 min., EDTA solution $\mathrm{pH}: 8,700$ Watt microwave oven). The sections were removed from the microwave, cooled and washed in distilled water. They were then stained for Ki-67, Bcl-2 and Bax using automated method (Ventana, USA). Sections were applied primary antibodies for 30 minutes, including SP6 rabbit monoclonal antibody Ki-67 (1:200, Lab Vision, CA, USA), 100/D5 mouse monoclonal antibody Bcl-2 alpha Ab-1 (1:40, Novocastra, UK) and 2D2 mouse monoclonal antibody Bax (apoptosis marker) Ab-1 (1:75, Neomarkers, CA, USA). The sections were washed first in water with detergent and then in distilled water. The sections were kept in acid-free Harris Hematoxylin and washed in tap water for 5 seconds. And they were then kept in $80 \%$ alcohol and 95\% alcohol for 5 minutes. The sections were then air-dried, kept in xylene for 15 minutes, and covered with Entellan. The tonsils were stained simultaneously for $\mathrm{Ki}-67$ and $\mathrm{Bcl}-2$ and colon adenocarcinoma for Bax as positive controls. Negative controls were stained by skipping primary antibody incubation.

When the immunohistochemical staining was evaluated, all of a section was scanned using $4 \mathrm{x}$ and 10x magnification on the microscope (Eclipse E600, Nikon, Japan) for each antibody in each case and specimens that had totally lost chorionic villus or decidual component were re-defined. Due to tissue disintegration it was not possible to evaluate decidua in two Ki-67, one Bcl-2, and one Bax stained specimens while chorionic villus was not examined in one Bcl-2 stained case.

$\mathrm{Ki}-67$ index was calculated as the number of positive nuclear immune staining in a total of 1000 cells in randomized areas consisting of decidual stromal cells and cytotrophoblastic cells lining the chorionic villi.

The positive cytoplasmic staining percentage for $\mathrm{Bcl}-2$ and Bax was determined by counting the number of cells staining positively in the decidua and chorionic villi and these were then classified into 4 groups by semiquantitative evaluation: 0 : no staining; 1 : 1-25\%; 2 : $26-50 \%$; $3: 51-75 \%$ and $4: 75-100 \%$. Statistical analysis of the obtained data was performed by SPSS 10.0 statistical package (SPSS Inc., Chicago, IL, USA) using Mann-Whitney U test, Pearson's Chi-Square test and Spearman's rank correlation test.

\section{RESULTS}

We re-evaluated 81 specimens of 66 patients in this study. One case that did not have adequate tissue for immunohistochemical evaluation was excluded from the study and a total of 80 specimens from 65 patients were used. Among 65 patients aged between 20 and 45; 21 had undergone evacuation abortion, 27 spontaneous abortion and 17 recurrent abortion.

Analysis of the rate of stromal cells with nuclear Ki-67 expression by groups revealed 3.73 for evacuation group, 0.74 for spontaneous abortion group and 0.64 for recurrent abortion group (Figure 1). Statistical analysis of these rates showed a significant difference between the evacuation group and spontaneous and recurrent abortion groups $(\mathrm{p}=0.002)$. Ki-67 expression in stromal cells was higher in the evacuation group than the spontaneous and recurrent abortion groups. Similarly, analysis of the nuclear Ki-67 expression in the cytotrophoblastic cells lining the chorionic villi produced a mean value of 38.49 for the evacuation group, 7.69 for the spontaneous abortion group and 5.04 for the recurrent abortion group (Figure 2). A statistically significant difference was found between the evacuation group and spontaneous and recurrent abortion groups for these rates as well $(\mathrm{p}<0.001)$. Advanced analysis showed this difference to be due to the difference between the evacuation-spontaneous and evacuation-recurrent groups. The rate of Ki-67 positive cells in villous cytotrophoblasts in the evacuation abortion specimens was higher than in the spontaneous and recurrent abortion specimens.

Analysis of the specimens with cytoplasmic Bcl-2 expression in decidual stromal cells according to the groups showed expression in two specimens (10\%) in the evacuation group

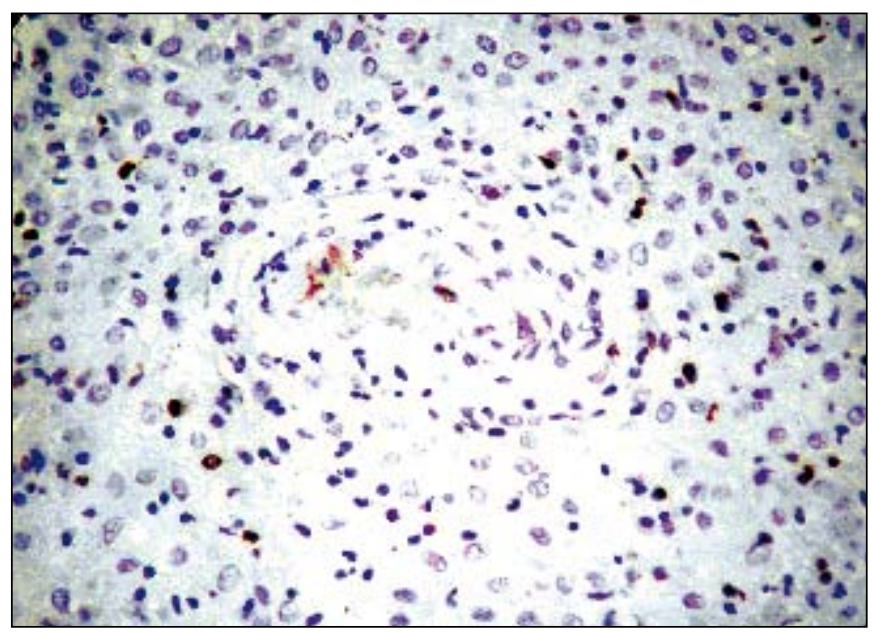

Figure 1: Nuclear Ki-67 staining in decidual stromal cells in abortion cases (x100). 
while there was no expression in the spontaneous and recurrent abortion groups (Figure 3). Statistical analysis of these rates showed no significant difference between the evacuation group and spontaneous and recurrent abortion groups $(\mathrm{p}=0.103)$. Analysis of the distribution of chorionic villi with cytoplasmic Bcl-2 expression showed Bcl-2 expression in more than half of the chorionic villi (51\% and over) in 15 specimens (75\%) in the evacuation group (Figure 4). A similar distribution of expression was found in 9 specimens (52.9\%) in both the spontaneous and recurrent abortion groups. No Bcl-2 expression was found in cytotrophoblastic cells. Statistical analysis of these rates showed no significant difference between the evacuation group and spontaneous and recurrent abortion groups $(\mathrm{p}=0.443)$.

Analysis of the percentage of decidual stromal cells with cytoplasmic Bax expression revealed no statistically significant difference between the groups $(\mathrm{p}=0.373)$. There was no staining in any of the evacuation abortion specimens. Expression was less than $1 \%$ in 3 of the 4 spontaneous abortion specimens with Bax expression and over $1 \%$ in 1 case. Expression that was less than 1\% was found in only one case of recurrent abortion (Figure 5). Analysis of the cytoplasmic Bax expression in the cyto- and syncytiotrophoblastic cells lining the chorionic villi showed score 1 staining (1-25\%) limited only to cytotrophoblastic cells in only one spontaneous abortion case $(\mathrm{p}=0.351)$ (Figure 6).

In decidual stromal cells, a moderately strong relation was found only between Bcl-2 and $\mathrm{Ki}-67$ when the correlation coefficients were analyzed $(\mathrm{p}=0.036, \mathrm{r}=0.267)$. Moderately strong positive correlation between $\mathrm{Bcl}-2$ and $\mathrm{Ki}-67$ in trophoblastic cells lining the chorionic villi with nonparametric correlation tests $(\mathrm{p}=0.000, \mathrm{r}=0.549)$. Comparison of the correlation values, corrected with partial correlation analysis between Ki-67, Bcl-2 and Bax for the different abortion types showed a moderately strong positive relation only between Ki-67 and Bcl-2 (for decidual stromal cells; $\mathrm{r}=0.411, \mathrm{p}=0.001$, for trophoblastic cells lining the chorionic villi; $\mathrm{r}=0.473, \mathrm{p}<0.001$ ).

\section{DISCUSSION}

The proliferation rate for both fetal villi and maternal decidua as evaluated by $\mathrm{Ki}-67$ expression showed this value to be significantly lower in the spontaneous and recurrent abortion groups than the control group. Although the proliferation rate was lower in recurrent abortion than spontaneous abortion, this difference was not statistically significant. Ki-67 expression was limited to

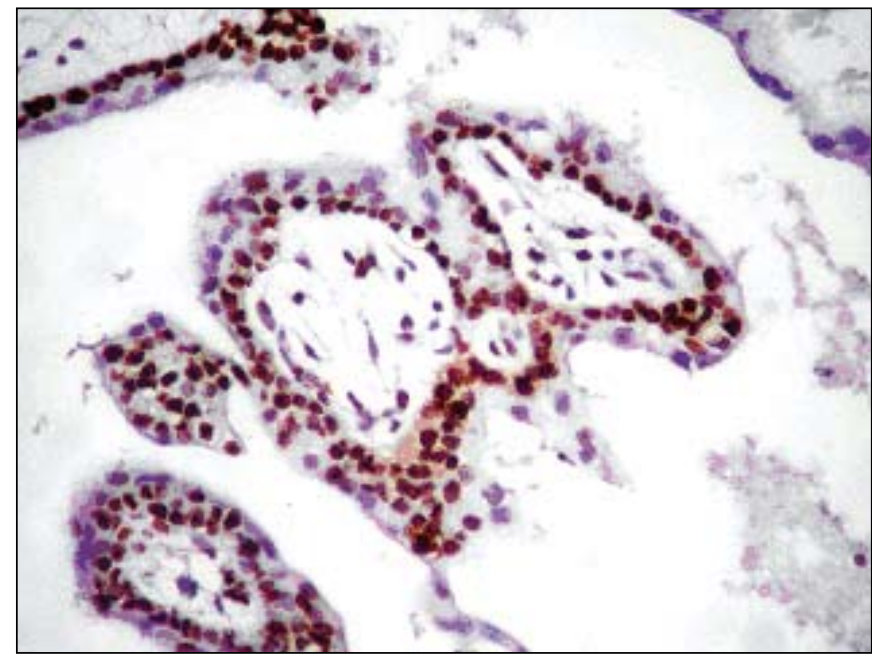

Figure 2: Nuclear Ki-67 staining in villous cytotrophoblasts in abortion cases (x100).

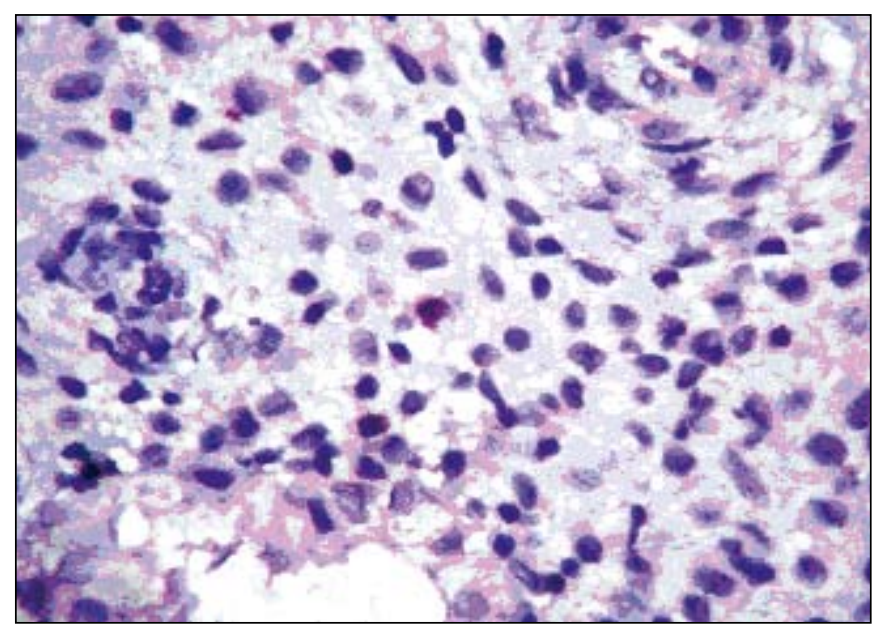

Figure 3: Cytoplasmic Bcl-2 staining in decidual stromal cells in evacuation abortion (x200).

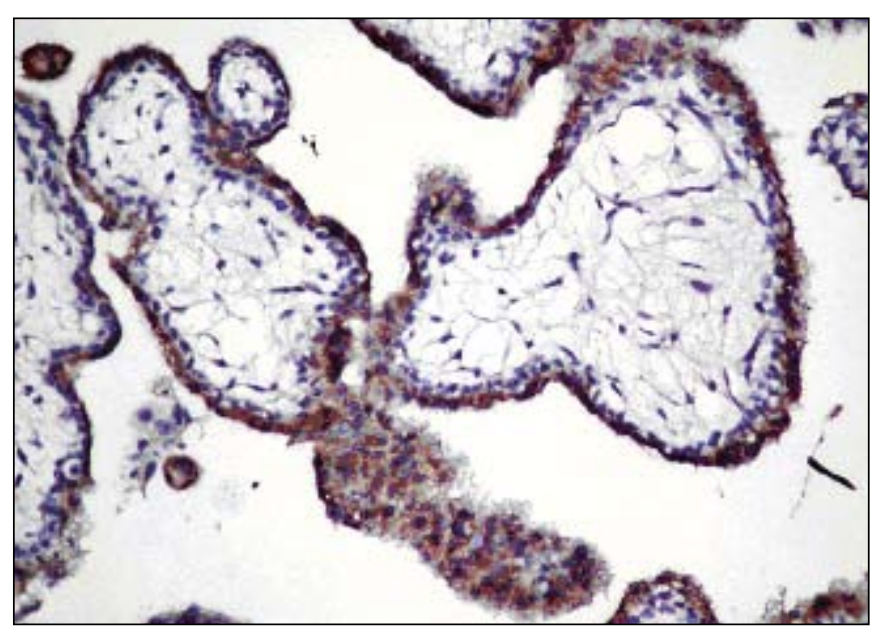

Figure 4: Cytoplasmic Bcl-2 staining in villous syncytiotrophoblasts in evacuation abortion (x100). 


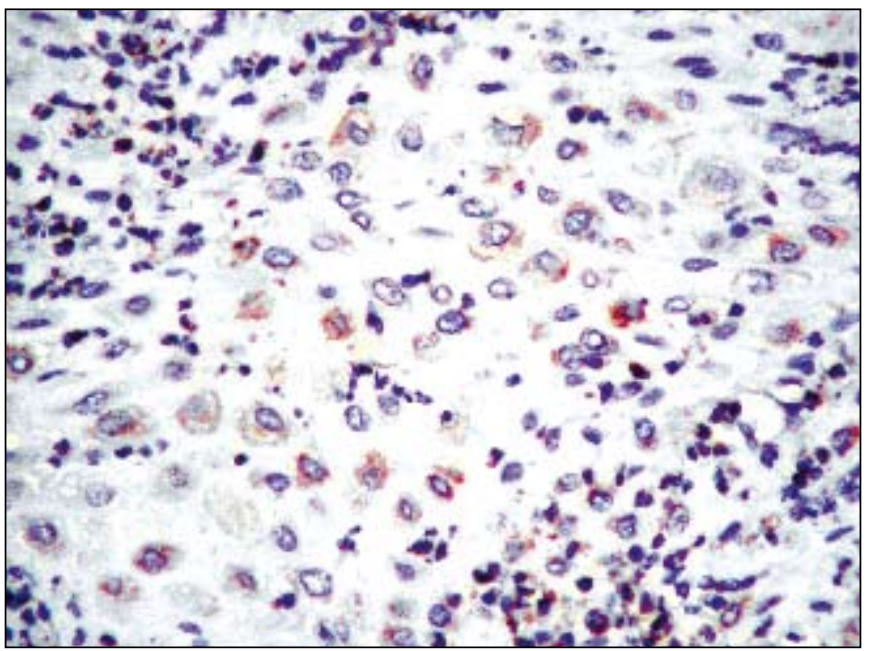

Figure 5: Cytoplasmic Bax staining in decidual stromal cells in spontaneous abortion (x200).

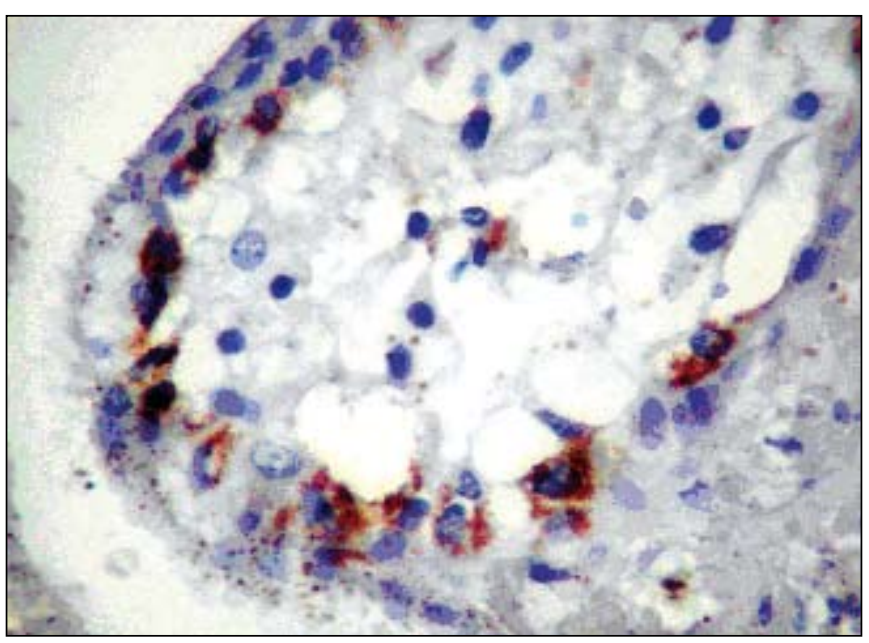

Figure 6: Cytoplasmic Bax staining in villous cytotrophoblasts in spontaneous abortion (x400).

the cytotrophoblastic cells lining the villi in fetal tissues and was more marked in the decidual perivascular areas.

Studies on cellular proliferation in placental tissue have focused on the trophoblastic cells as they are in direct contact with maternal blood and vital to maintain a successful pregnancy. Adequate proliferation is required both for trophoblastic cells and also villous stromal cells and blood vessels for the maturation and branching of villi. A study on proliferation markers in the human placenta during the normal course of pregnancy reported the highest Ki-67 expression in villous cytotrophoblasts was in the first trimester of pregnancy and it was lower in term placenta. Ki67 expression has not been reported in syncytiotrophoblasts during pregnancy. Results similar to Ki-67 were obtained for PCNA in the same study (9). Another study comparing placental tissue samples for cellular proliferation using the TUNEL method and $\mathrm{Ki}-67$ in spontaneous abortion specimens with normal and abnormal chromosome content has found significant decrease in cellular proliferation in the villous stroma and blood vessels in specimens with abnormal chromosomes. The proliferation rate was similar to placenta specimens making up the control group in abortion specimens with normal chromosomes. It was stated in this study that the inadequate development in villous blood vessels in spontaneous abortion specimens with abnormal chromosomal content cannot provide the necessary villous maturation and that this may explain some specimens of abortion and growth retardation. Similarly, decreased cellular proliferation was thought to explain changes in placental proteins such as the decreased $\alpha$ fetoprotein level in a group of pregnancies with aneuploidy. Hypoplastic placenta with inadequate development was also reported to produce a lower level of hCG that decreases the progesterone support of the decidua and leads to abortion in the early period (1). The significant decrease in the proliferative rate that we evaluated with $\mathrm{Ki}-67$ was found in villous cytotrophoblasts and maternal decidua in both spontaneous and recurrent abortion groups. A study comparing gestational trophoblastic disorders consisting of complete and partial hydatiform mole as well as invasive hydatiform mole with non-hydropic spontaneous abortion specimens for expressed proliferation markers (Ki-67, PCNA, and AgNOR) found significantly lower mean expression levels in the cytotrophoblastic cells of spontaneous abortion specimens due to gestational trophoblastic disorders. The highest levels of Ki-67 and PCNA were found in the hydatiform mole group and were associated with exaggerated trophoblastic proliferation (10).

We found Bcl-2 expression to be lower in the spontaneous and recurrent abortion groups than the evacuation group in this study although this was not statistically significant. This decrease in Bcl-2 expression was found in the syncytiotrophoblastic cells lining the villi in fetal tissues. We therefore thought loss of Bcl-2 expression we had found in the villi decreased the survival of villi and could lead to abortion. Similar villous Bcl-2 expression in spontaneous and recurrent abortion groups indicates that Bcl-2 expression may reflect the result of multiple factors rather than the cause in abortion. There was no decidual Bcl-2 expression in the spontaneous and recurrent abortion groups while it was present in two specimens in the evacuation group although in the form of scattered single cells. In contrast, we found decidual Bax expression 
in only five specimens (four spontaneous abortions and one recurrent abortion), although at low levels. This may indicate that Bax-related apoptosis may take place in decidual cells in a few abortion specimens. We found Bax expression in the villous cytotrophoblasts of only one spontaneous abortion specimen.

Kokawa et al. evaluated internucleosomal DNA fragments using the in situ analysis method to investigate potential apoptotic changes in human chorionic villi and decidua during the first trimester of pregnancy (4). They found apoptosis more frequently in cytotrophoblasts during pregnancy and more frequently in syncytiotrophoblasts in spontaneous abortion. They also found more apoptotic changes in decidual tissue in spontaneous abortions than in normal pregnancies. Based on these results, the investigators stated that there was a difference in cellular components between normal pregnancies and those pregnancies that end in spontaneous abortion and the increased apoptosis in syncytiotrophoblasts could prevent the development of the product of pregnancy. They suggested that the increased apoptotic activity in the decidual tissue that plays an important role in the nutrition of the developing embryo, protection from maternal immunological responses and the regulation of the uterine stromal invasion by trophoblasts could be responsible for the termination of pregnancy in spontaneous abortion. They also proposed that the increased apoptosis in decidual tissue in spontaneous abortion could trigger apoptotic activity in the syncytiotrophoblasts as well and that this could prevent embryonic development. However, Halperin et al. did not find any significant difference between normal pregnancies (1st and 2nd trimester) and missed abortion materials regarding the apoptotic cell percentage using flow cytometry and the propidium iodide staining method (11). The same study found no difference in the apoptosis incidence between placental tissue samples known to have normal or abnormal chromosomes. The investigators emphasized that these various changes may be due some kind of necrosis consisting of structural changes such as minimal changes in the nuclear morphology, swelling of organelles and cytoplasm and separation of plasma membrane instead of apoptosis.

Twoseparatestudies wherethecyto-andsyncytiotrophoblast Bcl-2 levels were evaluated in the human placenta found Bcl-2 expression to be at the lowest level at the early weeks of pregnancy (week 4-5) with levels increasing towards the term and mainly in the syncytiotrophoblastic cell cytoplasm (12). It has been reported that Bcl-2 expression in syncytiotrophoblasts that increases towards term may be important in maintaining pregnancy and protecting placental integrity by preventing loss of these cells (12). In contrast, there is a study reporting decreased $\mathrm{Bcl}-2$ expression towards term. This difference is thought to be due to the use of different procedures for $\mathrm{Bcl}-2$ immunostaining (12).

Astudyinvestigatingtherelationbetweendecidualizationand apoptotic regulations in an in vitro decidual cell culture (GG$\mathrm{AD}$ ) found Bax expression to have increased with no change in p53 protein levels in GG-AD cells that had differentiated to decidual cells when the temperature was increased from $33^{\circ} \mathrm{C}$ to $39^{\circ} \mathrm{C}(13)$. Another study evaluating Bax as the apoptotic marker during pregnancy found similar levels of Bax expression in cyto- and syncytiotrophoblasts in both initial and term placentas. It has therefore been postulated that continuous Bax expression during pregnancy balances the proliferative effect of trophoblastic cells (9). Cobellis et al. found, similar to our study, significantly increased Bax expression levels in both fetal cytotrophoblastic cells and maternal decidual tissue in first trimester abortion material (spontaneous or recurrent) compared to the products of pregnancies terminated voluntarily (14). Another study investigating genes associated with angiogenesis and apoptosis in chorionic villi with semi-quantitative reverse transcriptase-polymerase chain reaction analysis has found the expression of 12 apoptosis-related genes including Bax to be higher than in the control group (15).

In conclusion, we found that proliferation rate decreased in fetal villus cytotrophoblasts and maternal decidua in spontaneous and recurrent abortions in contrast to normal pregnancies. We believe that the loss of Bcl-2 expression in the syncytiotrophoblasts lining the chorionic villi can lead to abortion in some cases. However, the findings from spontaneous and recurrent abortion cases did not support the notion that different mechanisms may be effective in these two groups.

\section{Acknowledgement}

We would like to thank Assoc. Prof. Mehmet Zencir for his help in the biostatistical analysis of this study

\section{REFERENCES}

1. Qumsiyeh MB, Kim KR, Ahmed MN, Bradford W: Cytogenetics and mechanisms of spontaneous abortions: increased apoptosis and decreased cell proliferation in chromosomally abnormal villi. Cytogenet Cell Genet 2000, 88:230-235

2. Fox H: The placenta in abortion. In Fox H (Ed): Pathology of the placenta. 1st ed., New York, Saunders, 1978, 258-285

3. Stallmach T, Hebisch G: Placental pathology: its impact on explaining prenatal and perinatal death. Virchows Arch 2004, 445:9-16 
4. Kokawa K, Shikone T, Nakano R: Apoptosis in human chorionic villi and decidua during normal embryonic development and spontaneous abortion in the first trimester. Placenta 1998, 19:2126

5. Toki T, Horiuchi A, Ichikawa N, Mori A, Nikaido T, Fujii S: Inverse relationship between apoptosis and Bcl-2 expression in syncytiotrophoblast and fibrin-type fibrinoid in early gestation. Mol Hum Reprod 1999, 5:246-251

6. Kokawa K, Shikone T, Nakano R: Apoptosis in the human uterine endometrium during the menstrual cycle. J Clin Endocrinol Metab 1996, 81:4144-4147

7. Lea RG, Al-Sharekh N, Tulppala M, Critchley HOD: The immunolocalization of Bcl-2 at the maternal-fetal interface in healthy and failing pregnancies. Hum Reprod 1997, 12:153-158

8. Shikone T, Yamoto M, Kokawa K, Yamashita K, Nishimori K, Nakano R: Apoptosis of human corpora lutea during cyclic luteal regression and early pregnancy. J Clin Endocrinol Metab 1996, 81:2376-2380

9. Danihel L, Gomolcák P, Korbel M, Pruzinec J, Vojtassák J, Janík P, Babál P: Expression of proliferation and apoptotic markers in human placenta during pregnancy. Acta Histochem 2002, 104:335-338

10. Kale A, Söylemez F, Ensari A: Expression of proliferation markers (Ki-67, proliferating cell nuclear antigen and silverstaining nucleolar organizer regions) and of p53 tumor protein in gestational trophoblastic disease. Am J Obstet Gynecol 2001, 184:567-574
11. Halperin R, Peller S, Rotschild M, Bukovsky I, Schneider $D$ : Placental apoptosis in normal and abnormal pregnancies. Gynecol Obstet Invest 2000, 50:84-87

12. Ishihara N, Matsuo H, Murakoshi H, Laoag-FernandezJ, Samoto T, Maruo T: Changes in proliferative potential, apoptosis and Bcl2 protein expression in cytotrophoblasts and syncytiotrophoblasts in human placenta over the course of pregnancy. Endocrine Journal 2000, 47:317-327

13. Akcali KC, Gibori G, Khan SA: The involvement of apoptotic regulators during in vitro decidualization. Eur J Endocrinol 2003, 149:69-75

14. Cobellis L, De Falco M, Torella M, Trabucco E, Caprio F, Federico E, Manente L, Coppola G, Laforgia V, Cassandro R, Colacurci $N$, De Luca A: Modulation of Bax expression in physiological and pathological human placentas throughout pregnancy. In Vivo 2007, 21(5):777-783

15. Choi HK, Choi BC, Lee SH, Kim JW, Cha KY, Baek KH: Expression of angiogenesis-and apoptosis-related genes in chorionic villi derived from recurrent pregnancy loss patients. Mol Reprod Dev 2003, 66:24-31 